Кеба Мирослав Свгенович, старший викладач кафедри бальної хореографії Київського національного університету культури і мистецтв ORCID: 0000-0003-4468-0944 keba.kiev@ukr.net

\title{
ЕСТЕТИЧНА ВИРАЗНІСТЬ СПОРТИВНОГО БАЛЬНОГО ТАНЦЮ
}

Мета статті полягає в теоретичному осмисленні специфіки засобів виразності в спортивних бальних танцях як інструментарію для створення індивідуального стилю виконання. Методологія дослідження. В процесі дослідження специфіки засобів хореографічної виразності в спортивних бальних танцях для розгляду теоретичних концепцій та практики танцювальних виступів в сукупності застосовано комплексний підхід. Постановка мети статті актуалізує застосування загальнонаукових та мистецтвознавчих методів: аналітичного, термінологічного, типологічного методів, методу співставлення, а також методів філософсько-естетичного та мистецтвознавчого аналізу. Наукова новизна. Досліджено проблематику виражальних засобів та художньо-естетичних аспектів спортивного бального танцю як виду танцювального мистецтва; виявлено та проаналізовано фактори, що впливають на посилення хореографічної виразності; розглянуто процес формування індивідуального стилю виконання спортивного бального танцю у контексті розробки особистісно-орієнтованого підходу до застосування засобів естетичної виразності. Висновки. Естетична виразність у спортивному бальному танці проявляється за умови наявності естетичних властивостей та ілюструються метафорою, що надається абстрактною структурою танцю. Отже спортивний бальний танець може виражати неособисті емоції, відчугтя та почуття, художні ідеї або мету, соціокультурну ідентичність та/або якості, пов'язані з музичним супроводом або ті, що передаються ними. Акцент у виступах танцювальними парами робиться на художньому вираженні танцю як форми спілкування, що схожа на мову, через цілеспрямовані дії, знаки, символи чи жести. Специфіка становлення індивідуального стилю танцювальної пари залежить від особливостей особистісно-орієнтованого підходу до вибору головних та додаткових засобів хореографічної виразності.

Ключові слова: спортивні бальні танці, індивідуальний стиль, засоби хореографічної виразності, естетичні особливості.

Кеба Мирослав Евгеньевич, старший преподаватель кафедры бальной хореографии Киевского национального университета культуры и искусств

Эстетическая выразительность спортивного бального танцю

Цель статьи заключается в теоретическом осмыслении специфики средств выразительности в спортивных бальных танцах как инструментария для создания индивидуального стиля исполнения. Методология исследования. В процессе исследования специфики средств хореографической выразительности в спортивных бальных танцах для рассмотрения теоретических концепций и практики танцевальных выступлений в совокупности применен комплексный подход. Постановка целей статьи актуализирует применение общенаучных и искусствоведческих методов: аналитического, терминологического, типологического методов, метода сопоставления, а также методов философско-эстетического и искусствоведческого анализа. Научная новизна. Исследована проблематика выразительных средств и художественно-эстетических аспектов спортивного бального танца как вида танцевального искусства; выявлены и проанализированы факторы, влияющие на усиление хореографической выразительности; рассмотрен процесс формирования индивидуального стиля исполнения спортивного бального танца в контексте разработки личностно-ориентированного подхода к применению средств эстетической выразительности. Выводы. Эстетическая выразительность в спортивном бальном танце проявляется при наличии эстетических свойств и иллюстрируются метафорой, которая предоставляется абстрактной структурой танца. Итак спортивный бальный танец может выражать неличные эмоции, ощущения и чувства, художественные идеи или цели, социокультурную идентичность и / или качества, связанные с музыкальным сопровождением или те, что передаются ими. Акцент в выступлениях танцевальными парами делается на художественном выражении танца как формы общения, похожей на язык, через целенаправленные действия, знаки, символы или жесты. Специфика становления индивидуального стиля танцевальной пары зависит от особенностей личностно-ориентированного подхода к выбору главных и дополнительных средств хореографической выразительности.

Ключевые слова: спортивные бальные танцы, индивидуальный стиль, средства хореографической выразительности, эстетические особенности.

Keba Myroslav, Senior Lecturer, Ballroom Choreography Department, Kiev National University of Culture and Arts Aesthetic expressiveness of sports ballroom dance

The purpose of the article is to theoretically comprehend the specifics of expressive means in sports ballroom dancing as a tool for creating an individual style of performance. Methodology. In the process of researching the

СКеба М. Є., 2019 
particulars of the means of choreographic expressiveness in sports ballroom dancing, an integrated approach was taken to consider the theoretical concepts and practice of dance performances. The goal-setting of the article actualizes the application of general scientific and art history methods: analytical, terminological, typological methods, a method of comparison, as well as methods of philosophical-aesthetic and art historical analysis. Scientific novelty. The problems of expressive means and artistic and aesthetic aspects of sports ballroom dance as a form of dance art are investigated; identified and analyzed factors affecting the enhancement of choreographic expressiveness; The process of forming an individual style of performing sports ballroom dance in the context of developing a personality-oriented approach to the use of aesthetic, expressive means is considered. Conclusions. Aesthetic expressiveness in sports ballroom dancing is manifested in the presence of aesthetic properties and is illustrated by a metaphor that is provided by the abstract structure of the dance. So sports ballroom dance can express impersonal emotions, feelings, and feelings, artistic ideas or goals, sociocultural identity, and/or qualities associated with musical accompaniment or those that are transmitted by them. The emphasis in the performances by the dancing couples is on the artistic expression of the dance as a form of communication similar to a language through targeted actions, signs, symbols, or gestures. The specifics of the formation of the individual style of a dancing couple depends on the characteristics of a personality-oriented approach to the choice of the primary and additional means of choreographic expressiveness.

Key words: sports ballroom dancing, individual style, means of choreographic expressiveness, aesthetic features.

Актуальність теми дослідження. Специфіка спортивного бального танцю, як виду танцювального мистецтва, що на сучасному етапі отримав значного розвитку, полягає в унікальному синтезі мистецтва та спорту. Розгляд та осмислення науковцями теоретичних і практичних питань сучасного спортивного бального танцю наразі значно поступається темпам його розвитку. Однією з актуальних проблем, що потребує наукового дослідження є художньо-естетичні аспекти виступу виконавців.

Стандартизовані засоби виразності, засвоєння яких забезпечує посилення спортивної майстерності танцювальних пар, а їх використання сприяє підвищенню показників технічної підготовки та дозволяють створити індивідуальну манеру виступу, що підкреслює рівень технічної підготовки, пластичність рухів та артистизм не є загальноприйнятими та й досі не отримали відповідного наукового осмислення 3 мистецтвознавчих позицій.

Мета статті полягає в теоретичному осмисленні специфіки засобів виразності в спортивних бальних танцях як інструментарію для створення індивідуального стилю виконання.

Аналіз публікацій. Проблематика естетичних засобів хореографічної виразності спортивних бальних танців останнім часом привертає увагу багатьох дослідників. Р. Воронін у науковому дослідженні «Філософсько-естетичні та художні аспекти танцювального мистецтва: спортивний бальний танець, друга половина XX століття» робить одну 3 перших спроб визначити науковий підхід до вирішення актуальних проблем подальшого розвитку спортивного бального танцю, використовуючи в якості методологічної бази філософські концепції, пов’язані з визначенням природи спорту та мистецтва, розробивши модель структури виконавської майстерності в спортивному бальному танці [2].

Деякі аспекти засобів виразності у спортивних бальних танцях як головних показників оцінювання виступів учасників, а саме артистизм та емоційність, розглядає М. Богданова в науковій публікації «Спортивний танець у системі бальної хореографії» [1]. Специфіку взаємодії між танцювальними партнерами та чинники впливу на сприйняття, насиченість й видовищність виступу розглядають О. Мерлянова та Ю. Василенко. У публікації «Виховання артистичності серед партнерів у спортивних бальних танцях та методологія розвитку видовищності» автори викладають педагогічну технологію підвищення спортивної майстерності танцювальних пар розроблену П. Кочеріним та С. Бурановою [4], побудовану на засвоєнні засобів виразності, поєднанні емоційної складової виконавців, узгодженості їх дій та творчому підході до процесу тренування [5].

Виклад основного матеріалу. Спортивний бальний танець, домінантою естетичної структури в якому є рух, як образотворчий засіб, та пластика, як виражальний, утворює окрему підсистему в системі бальної хореографії, вирізняючись високим рівнем техніки виконання та синтезовано-модернізованими модифікаціями в хореографічному мистецтві. Водночас його змагальність в загальносоціальному контексті є важливою ланкою між спортом та мистецтвом.

Відповідно до естетичного визначення М. Бредслі мистецтва як «спеціального розміщення умов для отримання досвіду яскраво вираженого естетичного характеру» [7, p. 725], багато видів спорту є мистецтвом, оскільки гра в естетичних цілях є частиною оцінки в одних видах спорту, а в інших нерідко $є$ бажаною. На думку Д. Холта, якщо краса, створена в мистецтві не повинна бути реалізована з будь-якою подальшою метою, то вона може й не мати транс естетичної мети, тоді спорт буде тривіально виключено 3 художнього класу, оскільки естетичні ефекти будуть або несуттєвими або важливими лише в якості засобу для досягнення мети або перемоги [9, р. 138]. Л. Гуаріно стверджує, що художній танець не лише досить фізично вимогливий, щоб вважатися спортом, але й досить конкурентоздатний, щоб відповідати 
вимогам [7, pp. 77-78]. Відповідно якщо танець не обов'язково має бути художнім, проте він $є$ художньою формою, то художній танець не обов'язково повинен бути змагальним, проте він може вважатися спортом або «спортивною формою», коли він конкурентоздатний.

Складність розміщення спортивного бального танцю в метафізичних категоріях, розроблених 3 урахуванням інших форм мистецтва пояснюється наявністю в ньому суттєвих тілесних аспектів (розум в безпосередньому взаємозв' язку з тілом танцюриста бере участь в процесі створення, виконання та оцінки танців), що ускладнюють питання про те, як і чому його можна позиціонувати як мистецтво.

На думку Р. Вермей, щоб осмислити спортивний бальний танець як художню практику важливо зрозуміти що дана практика передбачає розуміння специфіки функціонування естетики [11].

Отже, досвід вважається естетичним, коли об'єкт уваги сприймається як самоцінний і таке сприйняття супроводжується естетичними емоціями, оскільки естетичні емоції - це знання, що підтверджують цінність об’єкта та підтверджують наявність естетичного досвіду.

Танець належить до системи мистецтв, оскільки усі мистецтва по суті є символами і відрізняється від інших мистецтв лише тим, що його символ або «первинна ілюзія» є символом віртуальної сили або жесту, а не віртуального часу (як символ музики), віртуального простору (як символ пластики) або ілюзії життя (символ поезії). Оскільки виразність присутня в усіх танцях, спортивний бальний танець можемо позиціонувати як особливо виразну форму мистецтва, що включає «дію» (необхідну рису танцю) чітко визначеним чином $[10, \mathrm{p} .86]$.

Наприкінці XX ст. відомий дослідник М. Бердслі стверджував, що виразність - необхідна умова для танцю як виду мистецтва, вона присутня коли рухи наділені більш «інтенсивними вольовими якостями, такими як родзинка, енергійність, жвавість, експансивність або значимість», ніж це потрібно для виконання будь-яких практичних функцій рухів я роботи. Відповідно виразність за М. Бердслі - це те, що перетворює інші форми рухів в танцювальні рухи [7, p. 31].

На основі аналізу філософських досліджень специфіки танцювальних засобів виразності В. Брігіншоу, Д. Марголіса, А. Дейлі та С. Коен виявлено, що вираження в танці осмислюється на основі чотирьох категорій:

- суб'єктивістські теорії, що конкретно пов'язують вираження в танці з емоціями людини, яка створила або виконує танець;

- натуралістичні теорії, що передбачають шлях переходу до природи або тіла конкретного танцюриста (танець виражає почуття через рухи, а не через будь-які особисті почуття, виражені мімікою обличчя) [6, p. 178];

- експресіоністичні теорії, відповідно до яких танець робить виразним його зміст;

- семіотичні теорії, відповідно до яких виразним танець робить його формальна структура.

В. Іванов пропонує розглядати такі естетичні поняття як виразність, стиль та втілення художнього образу як сенсоутворюючи в процесі визначення ступеню художньої значимості в спортивних бальних танцях [3, С. 72-81].

На думку М. Богданової, емоційні переживання танцюристів (експресія, виразність рухів та міміка) проходить через поведінковий рівень (проявляється через дії, рухи та реакції моторного характеру), набуває індивідуальних вербальних виражень на суб'єктивному рівні та створює унікальний художній образ після осмислення i трансформації індивідуально-типологічних особливостей на психофізіологічному рівні [1, с. 216].

У спортивному бальному танці на збільшення виразності впливає такі фактори, як:

- використання оригінальних зв'язок та поєднань;

- ступінь узгодження дій партнерів (даний засіб виразності спортивного бального танцю є одним 3 провідних та свідчить про рівень майстерності пари);

- артистизм та пластичність рухів - дозволяють донести до глядача музично-художній образ танцювальної композиції;

- оригінальні міміка, жести та пози;

- особистісно-орієнтований підхід;

- відповідний вибір музичного супроводу;

- індивідуальний стиль танцюристів.

Використання танцювальною парою оригінальних зв'язок та поєднань надають відчуття оригінальності, новизни та унікальності танцювальної композиції. Творчий процес пошуку та використання незвичних поєднань та зв'язок між танцювальними рухами, конструювання їх найрізноманітніших варіантів, експериментування з багатоманітними поєднаннями простих рухів суттєво впливає на збагачення даних засобів виразності. 
Раціональна кількість та відповідність певній частині композиції таких засобів виразності спортивних бальних танців як оригінальні міміка, жести та пози надають виступу танцювальної пари чіткості, логічності та завершеності. Аналіз виступів танцювальних пар дозволив зробити висновок, що істотні переваги пар-переможниць безпосередньо пов'язані з раціональним підходом до визначення місця та часу використання в композиції структури, форми та емоційності пози. Відповідно до факторів посилення естетичного та емоційного сприйняття танцювальних поз та рухів належить точність підібраних міміки та жестів

У контексті даного дослідження особистісно-орієнтований підхід розуміється як індивідуальні уподобання в процесі вибору музичного супроводу, а також головних та додаткових засобів хореографічної виразності.

Вдалий вибір музичного супроводу, що відповідає формі та змісту танцювальних рухів, серед різноманітних за жанром, характером, музичною виразністю та експресією музичних творів дозволяє розкрити наявний потенціал руху танцювальної пари та надати виступу яскравий індивідуальний характер

Становлення індивідуального стилю танцюристів залежить від особистіно-орієнтованої організації процесу тренування: спрямованості навчально-тренувальних занять на вияв особливостей характеру, мотивацій, схильностей, інтересів, танцювальної манери та переваг танцюриста.

Р. Воронін, при визначенні індивідуального художнього стилю танцюриста пропонує використовувати модель виконавської майстерності танцюриста, в якій відображені наступні компоненти:

- пластика (основу танцю становлять зображально-виражальні можливості, що закладені в людській тілесності та реалізуються в русі та пластиці, відповідно виражальну силу людського тіла зумовлює саме його пластична природа);

- музичність (вона сповнює танець певним художньо-образним сенсом та надає емоційну схвильованість та натхненність);

- дуетність (у розумінні досягнення ефекту синхронності виконання та єдності емоційного спрямування танцювальної пари за умови яскраво виражених чоловічого ат жіночого початків у взаємодії партнерів);

- єдність (органічність в загальній поведінці на паркеті та в кожному русі танцю) [2, с. 24].

Певний крок виконаний танцюристом, манера виконання, який крок він виконає після цього, як саме даний крок зроблено відносно партнера, специфіка ритму музичного супроводу, колір, лінія, текстура його костюму та інші аспекти створюють нематеріальну віртуальну форму. За Р. Вермей, те, що зроблено (під час виступу танцювальної пари) $є$ фактичним рухом, а те, що створено (художній образ) $\epsilon$ нематеріальною віртуальною формою [11].

Спортивний бальний танець як твір мистецтва завжди перебуває в процесі - лише безпосередньо під час виступу танець може стати об’єктом уваги, якому надається цінність. Р. Вермей акцентує на тому, що естетичний вибір для танцюриста означає, що у головна увага приділена не фактичному виконанню кроків та рухів, а осмисленням рухів як засобом створення єдиного значимого цілого, невід'ємними складовими якого $€$ взаємодія структур руху та взаємозв'язок компонентів танцювального середовища.

Наукова новизна. Досліджено проблематику виражальних засобів та художньо-естетичних аспектів спортивного бального танцю як виду танцювального мистецтва; виявлено та проаналізовано фактори, що впливають на посилення хореографічної виразності; розглянуто процес формування індивідуального стилю виконання спортивного бального танцю у контексті розробки особистісно-орієнтованого підходу до застосування засобів естетичної виразності.

Висновки. Естетична виразність у спортивному бальному танці проявляється за умови наявності естетичних властивостей та ілюструються метафорою, що надається абстрактною структурою танцю. Отже спортивний бальний танець може виражати неособисті емоції, відчуття та почуття, художні ідеї або мету, соціокультурну ідентичність та/або якості, пов'язані з музичним супроводом або ті, що передаються ними. Акцент у виступах танцювальними парами робиться на художньому вираженні танцю як форми спілкування, що схожа на мову, через цілеспрямовані дії, знаки, символи чи жести. Специфіка становлення індивідуального стилю танцювальної пари залежить від особливостей особистісноорієнтованого підходу до вибору головних та додаткових засобів хореографічної виразності. 


\section{Jimepamypa}

1. Богданова М .В. Спортивний танець у системі бальної хореографії. Украӥнська культура: минуле, сучасне, иляхи розвитку. 2014. Вип. 20. С. 214-217.

2. Воронин Р. Е. Философско-эстетические и художественные аспекты танцевального искусства: спортивный бальный танеи, вторая половина ХХ века : автореферат дис. канд. искусствоведения : 17.00 .09 / СанктПетербургский Гуманитарный университет профсоюзов. Санкт-Петербург, 2007. 26 с.

3. Иванов В. В. К вопросу о сущности «вхождения» художественного языка в спорт. Вестник аспирантуры СПбГАФК им. П.Ф. Лесгафта. Санкт-Петербург. 2002. С. 72-81.

4. Кочерин П. М., Буранова Е. В. Методика воспитания эстетической выразительности в спортивних танцах. Педагогико-психологические и медико-биологические проблемы физической культуры и спорта. 2011 . № 3 (20). С. 91-97.

5. Мерлянова О. А., Василенко Ю. В. Виховання артистичності серед партнерів у спортивних бальних танцях та методологія розвитку видовищності. Young Scientist. 2018. № 11 (63). С. 197-201.

6. Cohen S. J. Dance as a Theatre Art: Source Readings in Dance History from 1581 to the Present, Second Edition, Highstown, NJ: Princeton Book Publishers, 1992. p. 178.

7. Beardsley M. C. What Is Going On in a Dance? Dance Research Journal. 1982. № 15. pp. 31-72.

8. Guarino L. Is dance a sport? A twenty-first-century debate. Journal of Dance Education. 2015. № 15 (2). pp. 77-80.

9. Holt J. Sport as art, dance as sport. AUC Kinanthropologica. 2017. Vol. 53. № 2. pp. 138-145.

10. Pakes A. The Plausibility of a Platonist Ontology of Dance. Thinking Through Dance: The Philosophy of Dance Performance and Practices. J. Bunker, A. Pakes and B. Rowell (eds.). Hampshire: Dance Books, Ltd., 2013. pp. 84-101.

11. Vermeij R. Aesthetic Expression. 2012. URL : https://wdced.com/2012/11/ruud-vermeij-aesthetic-expression/ (дата звернення 12.07.2019).

\section{References}

1. Bogdanova, M. V. (2014). Sport dance in the system of ballet choreography. Ukrainian culture: past, present, ways of development, Vol. 20, pp. 214-217 [in Ukrainian].

2. Voronin, R. E. (2007). Philosophical and aesthetic and artistic aspects of dance art: sports ballroom dance, the second half of the twentieth century. Abstract of C.Ed. St. Petersburg [in Russian].

3. Ivanov, V. V. (2002). On the issue of the essence of the «entry» of artistic language into sports. Bulletin of postgraduate studies St. Petersburg State Pharmacological University named after P.F. Lesgaft, pp. 72-81 [in Russian].

4. Kocherin, P. M., Buranova E. V. (2011). Methods of educating aesthetic expressiveness in sports dancing. Pedagogical-psychological and biomedical problems of physical education and sport, no. 3 (20), pp. 91-97 [in Russian].

5. Merlyanova, O. A, Vasilenko, Y. V. (2018). Artistic education among partners in sports ballroom dancing and methodology of entertainment development. Young Scientist, no. 11 (63), pp. 197-201 [in Ukrainian].

6. Cohen, S. J. (1992). Dance as a Theatre Art: Source Readings in Dance History from 1581 to the Present, Second Edition. Highstown, NJ: Princeton Book Publishers [in English]. English].

7. Beardsley, M. C. (1982). What Is Going On in a Dance? Dance Research Journal, no. 15, pp. 31-72 [in

8. Guarino, L. (2015). Is dance a sport? A twenty-first-century debate. Journal of Dance Education, no. 15 (2), pp. 77-80 [in English].

9. Holt, J. (2017). Sport as art, dance as sport. AUC Kinanthropologica, Vol. 53, no. 2, pp. 138-145 [in English].

10. Pakes, A. (2013). The Plausibility of a Platonist Ontology of Dance. Thinking Through Dance: The Philosophy of Dance Performance and Practices. J. Bunker, A. Pakes and B. Rowell (eds.). Hampshire : Dance Books, Ltd. pp. 84-101 [in English].

11. Vermeij, R. (2012). Aesthetic Expression. Available at : https://wdced.com/2012/11/ruud-vermeij-aestheticexpression/ [in English].

Стаття надійшла до редакиії 20.08.2019 р. 